\title{
SOIL MICROBIAL BIOMASS IN SEMI-ARID COMMUNAL SANDY RANGELANDS IN THE WESTERN BOPHIRIMA DISTRICT, SOUTH AFRICA
}

\author{
A. S. MOUSSA ${ }^{1, *}-$ L. VAN RENSBURG ${ }^{1}-$ K. KeLLNER $^{1}-$ A. BATIONO ${ }^{2}$ \\ ${ }^{1}$ School of Environmental Sciences and Development, North-West University \\ (Potchefstroom Campus), Private Bag X 6001 Potchefstroom 2520, South Africa \\ $\mathrm{Tel} / \mathrm{Fax}+27182992509$, \\ ${ }^{2}$ Tropical Soil Biology and Fertility, Institute of the International Center for Tropical \\ Agriculture (TSBFI-CIAT) P.O. Box 30677 Nairobi, Kenya \\ e-mail:plbasm@puk.ac.za
}

(Received $2^{\text {nd }}$ Feb 2006 ; accepted $10^{\text {th }}$ Apr 2007)

\begin{abstract}
Soil microbial biomass is considered as an important early indicator of changes that may occur in the long term with regard to soil fertility and constitutes an important source and sink of nutrients. In South Africa, rangeland monitoring has mostly focused on assessing changes of aboveground vegetation in response to land uses effects, but the associated changes at belowground soil level remain a topic of further research. The aim of this study was to explore soil microbial biomass at three sites under communal grazing management. Soils from grazed and adjacent ungrazed rangeland plots were collected at a depth of 0-25 cm towards the end of the rainy season in April 2005. The soil microbial biomass was characterized by analyzing the phospholipids ester-linked fatty acids. Soils were also analyzed for organic carbon, $\mathrm{pH}$, and total phosphorus. Results showed no statistically significant differences in organic carbon and soil microbial biomass between the grazed and ungrazed plots at any of the sites. Both organic carbon and soil microbial biomass were low, ranging from 0.06 to $0.11 \%$ and $489.28 \mathrm{pmol} \mathrm{g}^{-1}$ to $1823.04 \mathrm{pmol} \mathrm{g}^{-}$ ${ }^{1}$, respectively. Fourteen grass species were recorded during the vegetation surveys, and most occurred in low abundance. Plants supply organic materials as energy sources for microbial growth, so the low soil microbial biomass could be a reflection of the low vegetation abundance. This study provides essential baseline information regarding soil microbial activity never reported before in these rangelands. Further investigations are required for in-depth understanding of the underlying processes that regulate soil microbial biomass dynamics at these sites.
\end{abstract}

Keywords: soil microbial biomass; microbial community structure; vegetation composition, abundance and cover; soil quality.

\section{Introduction}

The management of soil as a natural resource is of utmost importance for sustainable agriculture, and an overall understanding of soil quality will allow management of the soil resource to ensure sustainable food, fiber, and feed production throughout the world. There is a global need for tools to evaluate the ramifications of soil resource management upon spatio-temporal changes in soil quality to ascertain sustainability of farm-management practices [13]. Soil quality depends on its natural composition and the changes caused by human use and management [36]. [16] indicated that as degradation takes place, soil properties change, particularly the soil microbial activity, and that high levels of microbial activity are fundamental in maintaining soil quality.

Considerable effort has been extended in the study of soil microbial processes associated with maintaining ecosystem stability with regard to the effects of anthropogenic activities [44]. There has been interest in the characterization of soil biodiversity and function in agricultural grasslands [5]. This interest has been driven by the need to develop grassland management strategies directed at manipulating the soil biota and to encourage a greater reliance on ecosystem self-regulation than on artificial 
inputs such as fertilizers and pesticides [53]. This interest has also come from the recognition that the organisms that live belowground regulate major ecosystem processes, but also because of the likelihood that feedbacks between aboveground and belowground communities have a key role in governing ecosystem functioning [6], [47], [17].

The soil-based biotic component is of fundamental importance on how ecosystems function, through determining nutrient cycling, decomposition and energy flow. Because of the relatively direct linkage between soils biological activity and many ecosystem-level processes (decomposition, nutrient mineralization), soils microorganisms provide a good opportunities for investigating ecosystem-level responses to disturbances and stress gradients [51]. Soil microbial biomass is the primary catalyst of biogeochemical processes as well as an energy and nutrient reservoir [44], [19], [20], [46], [55], [3], [22], [23], [31]. In low fertile soils with a high proportion of nutrients immobilized in the belowground living biomass, standard soil fertility tests are of little value. It makes more sense to measure the living soil microbial biomass and microbial activity [41], although the quantitative description of microbial diversity remains one of the most difficult tasks facing microbial ecologists [55]. Soil microbiological properties such as microbial biomass may be used as early and sensitive indicators of soil quality [8], for comparisons of soils under different managements [28], and that high levels of microbial activity are fundamental in maintaining soil quality [16]. Microbial metabolism in soil is limited by the availability and types of organic substrates [33], and the quantitative and qualitative differences in substrate supply between grasslands are responsible for the variation in microbial community [6], [29], [18], [19]. Furthermore, higher levels of plant production associated with greater plant diversity fostered a shift in microbial community composition [54].

In South Africa, rangelands are important ecosystems with more than $80 \%$ of the land used for pastoral production [43]. Three main rangeland management systems can be found: commercial and communal livestock ranching and game ranching. They differ in management structure, animal diversity, management of grazing resources and products [38]. Communal rangeland management is perceived as unproductive and unsustainable form of land use [1], [37]. In the Bophirima District, soil degradation has become of major concern, particularly in the communal managed rangelands [30]. There is considerable information on the state of the vegetation resources, but research on the associated processes that occur at belowground soil level is scarce. The purpose of this pilot study was to explore soil microbial biomass at three sites under communal grazing system. This study forms part of the Desert Margins Program (DMP) in South Africa. The aims of the DMP SA are to conserve and restore biodiversity in the desert margins through sustainable utilization, and to develop strategies to enhance ecosystem function and sustainable use in arid and semi-arid areas that are degraded and have reduced biodiversity associated with human and climate impact (K. Kellner, personal communication).

\section{Materials and methods}

\section{Study sites}

The study area is located in the western Bophirima District in the Ganyesa region (North-West Province, South Africa). Most of the land in this area is under tribal or 
state administration. Agriculture is mainly subsistence-oriented, and the main land use type is cattle and game farming based on extensive livestock production because of climatic constraints [30]. The climate is semi-arid, and annual rainfall ranges between 200 and $450 \mathrm{~mm}$, of which $80 \%$ falls in summer (October to March) and 20\% in winter (April to September). The vegetation in the area is classified as the savanna biome, and consists of the Kalahari thornveld and shrub bushveld vegetation types. Acacia erioloba is the most prominent tree in this area, associated with other Acacia species (A. tortilis, A. mellifera subsp. Detinens, A. luderitzii, A. haematoxylon) and other species such as Gravia flava, Boscia albitrunca [2], [43]. The herbaceous layer ranges from an essentially karroid type, e.g. Rhigozum trichotomum and the desert grasses Stripagrostis uniplumis and Schmidtia kalaharensis in the most westerly regions to a mesophytic grass layer, e.g. Themeda triandra and Heterotogon contortus in the east [43].

Three experimental rangelands sites Austrey, Southey and Tseoge implemented for the purpose of the Provincial LandCare program were selected. The sites are under communal grazing management, and their general characteristics are given in Table 1.

Table 1 General site characteristics

\begin{tabular}{|c|c|c|c|}
\hline Sites & Austrey & Southey & Tseoge \\
\hline Latitude/Longitude & $\mathrm{S} 26^{\circ} 28^{\prime} / \mathrm{EO} 24^{\circ} 10^{\prime}$ & $\mathrm{S} 26^{\circ} 39^{\prime} / \mathrm{EO} 23^{\circ} 50^{\prime}$ & $\mathrm{S}_{25^{\circ}} 59^{\prime} / \mathrm{EO}^{\prime} 3^{\circ} 31^{\prime}$ \\
\hline Altitude (m) & 1240 & 1148 & 1134 \\
\hline Annual rainfall (mm) & $300-400$ & $300-450$ & $200-350$ \\
\hline Soil forms & $\begin{array}{l}\text { - Clovelly form } \\
\text { - Hutton form } \\
\text { - Depth 900-1200 } \\
\text { mm }\end{array}$ & $\begin{array}{ll}\text { - } & \text { Clovelly form } \\
\text { - } & \text { Hutton form } \\
\text { - } & \text { Depth }>1500 \mathrm{~mm}\end{array}$ & $\begin{array}{l}\text { - Mispah form } \\
\text { - Depth }<250 \mathrm{~mm}\end{array}$ \\
\hline Grazing system & Communal & Communal & Communal \\
\hline
\end{tabular}

The soils are predominantly sandy $( \pm 95 \%$ sand), with low clay $( \pm 3 \%)$, soil organic carbon $( \pm 0.16 \%)$ and total phosphorus $\left( \pm 6.5 \mathrm{mg} \mathrm{kg}^{-1}\right)$. At the Austrey and Southey sites, the soils are from the Clovelly and Hutton forms, characterized by a yellow-brun apedal and a red apedal B orthic top soil horizon, respectively. At the Tseoge site, the dominant soils belong to the Mispath form, characterized by a hard rock orthic top soil horizon [39]. The three sites fall within the sweetveld category, which is defined as veld (grazing land) which remains palatable and nutritious when it is mature [43]. At the onset of this study, the herbaceous vegetation composition and cover were very low as shown in Fig 1 (e.g. Austrey site).

At each of the three sites, grazed and adjacent ungrazed plots of $110 \times 20 \mathrm{~m}^{2}$ size each were selected. They were established respectively in 2001 at Austrey and 2003 at Southey and Tseoge for the purpose of the LandCare program. Prior to the establishment of these plots, domestic livestock grazed the rangelands at each of the sites, and no specific management system was imposed. 


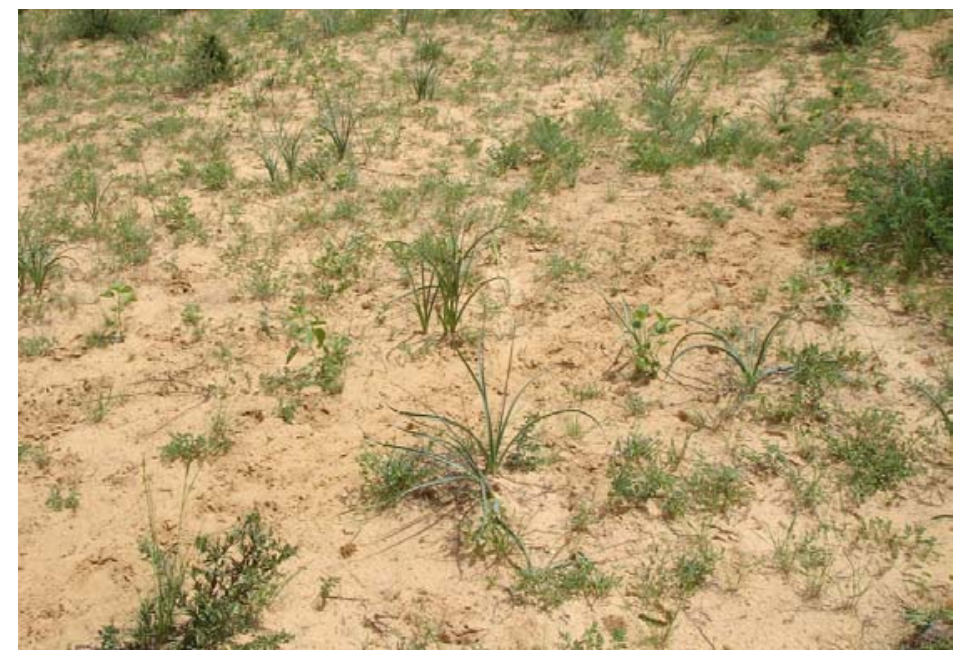

Figure 1. View of the state of the vegetation in the grazed plot at Austrey site

\section{Soil sampling and analyses}

Soils were sampled towards the end of the rainy season in mid-April 2005 in grazed and adjacent ungrazed plots. Because the plots were not replicated at each of the sites, pseudo-replicates samples were collected. The problem of pseudo-replication is omnipresent in most studies of grazing effects [42]. Each plot was divided in two subplots and composite sample of ten cores samples collected at a depth of $0-25 \mathrm{~cm}$ along two parallel transects running the length in each sub-plot was taken. Dead coarse organic materials and stones were removed from each sub-sample, which was then split in two parts, one for chemical analyses and the second one for microbial analyses. The latest one was put in sealed plastic bags and keep in icebox until transportation to the laboratory.

\section{Chemical analysis}

Soil $\mathrm{pH}\left(\mathrm{H}_{2} \mathrm{O}\right)$ was determined in $1: 2 \mathrm{v} / \mathrm{v}$ water-extract with a calibrated $\mathrm{pH}$ (Radiometer PHM 80, Copenhagen) at $25^{\circ} \mathrm{C}$, as described [32]. Total phosphorus (PBray 1) was determined by the Bray 1 method [10] and soil organic carbon (OC) was measured by the Walkley-Black method [49].

\section{Microbial analysis}

The characterization of soil microbial biomass and community structure was done by analyzing the ester-linked phospholipids fatty acids (PLFA) composition of the soil. The concentration of PLFA is a measure of viable microbial biomass [55] and is an effective tool for monitoring microbial responses to their environment. The soil microbial biomass was determined as described in [12]. Briefly, total lipids were extracted from a $5 \mathrm{~g}$ lyophilized soil according to a modified method [9] as described [52]. Silicic acid column chromatography was used to fractionate the total lipid extract into neutral lipids, glycolipids and polar lipids. The polar lipid fraction was transesterified to the fatty acid methyl esters (FAMEs) by a mild alkaline methanolysis [21]. The FAMEs were analyzed by capillary gas chromatography with flame ionization detection on a Hewlett-Packard 6890 series 2 chromatograph fitted with a 60 m SPB-1 column $(0.250 \mathrm{~mm}$ I.D., $0.250 \mu \mathrm{m}$ film thickness). Identification of peaks was done by 
gas chromatography/mass spectrometry of selected samples using a Hewlett-Packard 6890 interfaced with a Hewlett-Packard 5973 mass selective detector. Methyl nonadecanonate (C19:0) was used as the internal standard and the PLFA were expressed as equivalent peak responses to the internal standard. The total microbial biomass was expressed as pmol PLFA g ${ }^{-1}$ dry weight soil.

\section{Herbaceous composition}

The herbaceous composition was determined towards the end of the rainy season in mid-April 2005. The wheel-point method was used as described [27]. The survey was done along parallel transects running the length in each of the grazed and ungrazed plots. The nearest grass plant in a $45 \mathrm{~cm}$ radius was identified and recorded, and when no grass plant was present, it was considered as a bare ground. The survey was completed when $98 \%$ of the total variation in species composition had been sampled. The similarities in herbaceous composition between the grazed and ungrazed plots were determined using the $\mathrm{Z}$-index value:

$$
\mathrm{Z}(\%)=\left[(\mathrm{b} / \mathrm{a} * 100)^{*}(\mathrm{a}+\mathrm{b})\right] / \sum(\mathrm{a}+\mathrm{b})
$$

where $\mathrm{a}$ and $\mathrm{b}$ represent, respectively, the highest and the lowest frequency values of each grass identified. The more the $\mathrm{Z}$-index tends towards $100 \%$, the greater the similarity and the more it tends towards $0 \%$ the smaller the similarity [15].

\section{Data analysis}

Data of soil chemical and microbiological properties were analyzed by means of analysis of variance (ANOVA), and statistically significant differences between means were tested using Fisher Least Significant Difference (Fisher LSD) at $\mathrm{P}<0.05$ probability level. STATISTICA 7 (Stat Soft ${ }^{\circledR}$ ) was used for all statistics. Relationships between grass composition, soil microbial biomass and microbial community structure were investigated by means of canonical correspondence analysis (CCA) using the computer data analysis software CANOCO 4.5 [45].

\section{Results}

\section{Soil chemical properties}

Table 2 summarizes the soil chemical properties in grazed and ungrazed plots at three sites. Soil organic carbon (OC) and $\mathrm{pH}$ did not show any statistically significant differences between the grazed and ungrazed plots, although OC was slightly reduced in all grazed plots at all the study sites. Total phosphorus (P-Bray 1) showed a significant difference between the grazed and ungrazed plots at only Tseoge site $(\mathrm{p}=0.03)$.

Table 2. Soil chemical properties (standard error in bracket) in grazed and ungrazed plots

\begin{tabular}{llccc}
\hline Sites & Plots & $\mathrm{pH}\left(\mathrm{H}_{2} \mathrm{O}\right)$ & $\begin{array}{c}\text { Organic Carbon } \\
(\%)\end{array}$ & P-Bray $1\left(\mathrm{mg} \mathrm{kg}^{-1}\right)$ \\
\hline Austrey & Grazed & $5.5(0.05)$ & $0.09(0.01)$ & $6.3(0.22)$ \\
& Ungrazed & $5.5(0.03)$ & $0.11(0.02)$ & $6.6(0.07)$ \\
Southey & Grazed & $5.5(0.02)$ & $0.09(0.0009)$ & $8.5(1.2)$ \\
& Ungrazed & $5.6(0.07)$ & $0.09(0.002)$ & $7.8(1.1)$ \\
\hline
\end{tabular}




\begin{tabular}{llccl}
\hline Tseoge & Grazed & $7.1(0.01)$ & $0.05(0.0009)$ & $8.6(0.41)^{*}$ \\
& Ungrazed & $6.6(0.38)$ & $0.06(0.06)$ & $6.4(0.03)^{*}$ \\
\hline
\end{tabular}

* Significantly different at $\mathrm{p}<0.05$

\section{Microbial analysis}

\section{Soil microbial biomass}

The total phospholipids fatty acids (PLFA) a measure of the viable microbial biomass between the grazed and ungrazed plots are given in Fig. 2. Total PLFA ranged from $489.28 \mathrm{pmol} \mathrm{g}^{-1}$ in the grazed plot at Southey site to $1823.04 \mathrm{pmol} \mathrm{g}^{-1}$ at Austrey's grazed plot. PLFA was not statistically different between the grazed and ungrazed plots at any of the study sites. When comparing exclusively the grazed plots across the three sites, total PLFA showed statistically significant differences between the three sites $(\mathrm{p}=0.03$, Fig. 2).

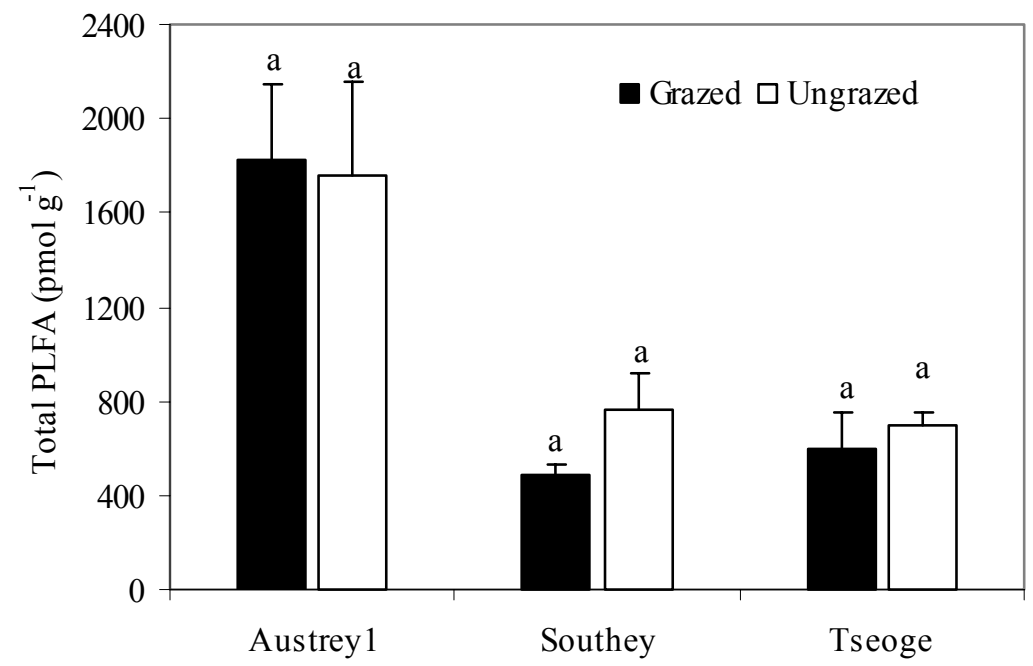

Figure 2. Total phospholipid fatty acids (Total PLFA) in grazed and ungrazed plots at the sites (values are means and bars represent standard errors). Means with same lower case letter are not statistically different between the grazed and ungrazed plots per site. $\mathrm{P}<0.05$

\section{Soil microbial community structure}

The microbial community structure expressed as the relative abundance of bacteria and fungi is presented in Fig. 3. Bacterial PLFA did not statistically vary between the grazed and ungrazed plots at any of the study sites. It ranged between $160.38 \mathrm{pmol} \mathrm{g}^{-1}$ at Southey's grazed plot to $641.61 \mathrm{pmol} \mathrm{g}^{-1}$ at Austrey site. Bacterial PLFA showed statistically significant difference between the grazed plots between the sites $(p=0.02$, Fig. 3a). The fungal PLFA did not differ statistically between the grazed and ungrazed rangelands at any of the three study sites, nor between the grazed plots exclusively $(\mathrm{p}=0.18)$. As for the bacterial PLFA, the fungal PLFA was higher in both the grazed and ungrazed rangelands at Austrey site, compared to the Southey and Tseoge sites (Fig. $3 \mathrm{~b})$. The fungal:bacterial ratio ( $\mathrm{F} / \mathrm{B}$ ratio), a measure of the proportion of fungi and bacteria within the microbial community, was not statistically different between the 
grazed and ungrazed plots at any of the sites (Fig. 3c). It did not differ significantly between the grazed plots across three sites $(\mathrm{p}=0.15)$.
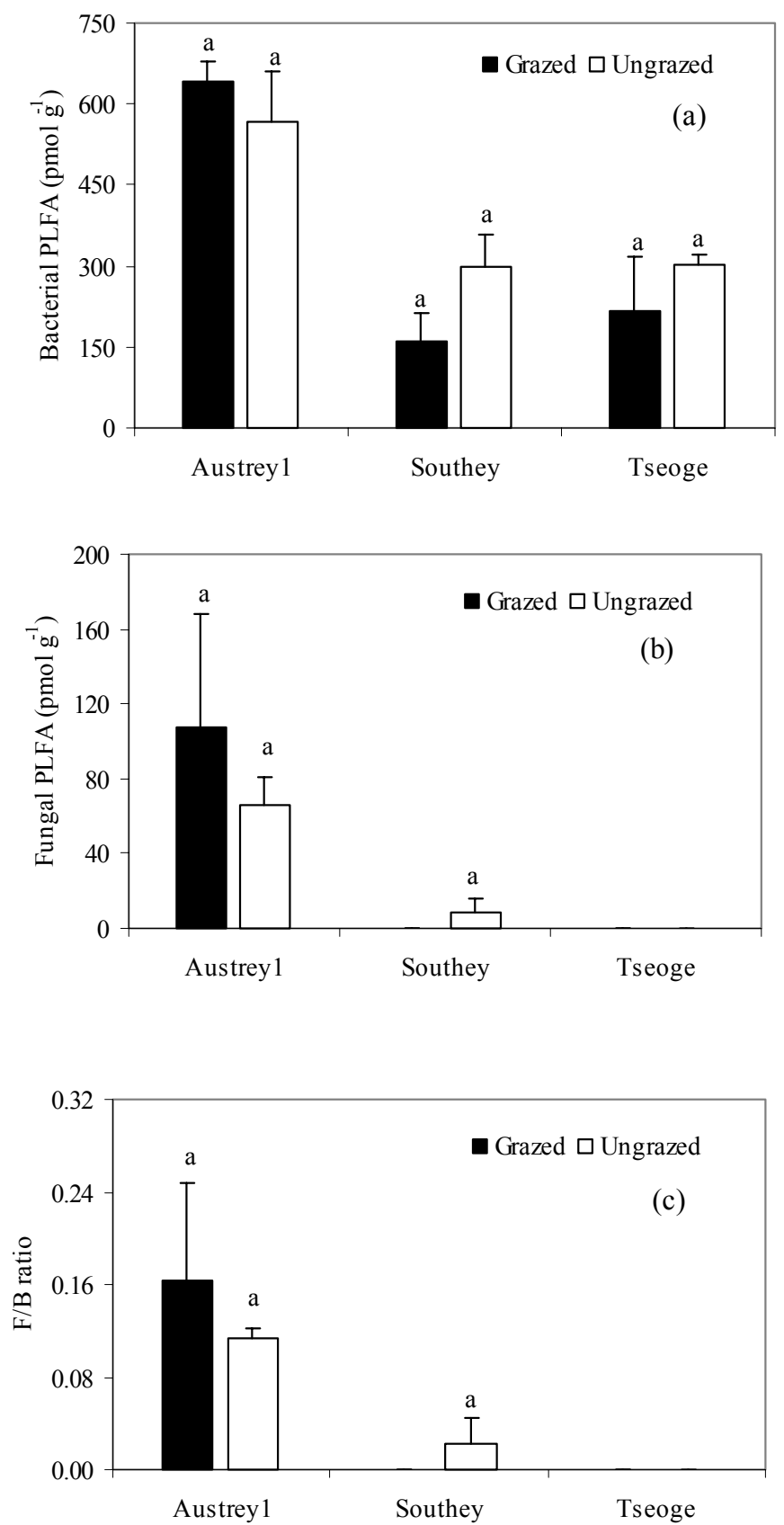

Figure 3. The microbial community structure: (a) bacterial PLFA (b), fungal PLFA, and (c) the fungal:bacterial ratio in the grazed and ungrazed plots at the sites. Means with same lower case letter are not statistically different between the grazed and ungrazed plots per site. $P<0.05$

\section{Herbaceous composition}

Fourteen grass species were monitored during the botanical survey. Most of the grass identified, occurred in low abundance in both the grazed and ungrazed plots (Table 3). The species were unevenly distributed across the three sites. Despite the low abundance across the three sites, the site at Austrey showed "relatively" greater species abundance, in both the grazed and ungrazed plots, compared to the Southey and Tseoge sites. The 
Z-indexes were $48.34 \%, 57.91 \%$ and $1.62 \%$, respectively at Austrey, Southey and Tseoge sites. The low Z-index at the Tseoge site $(1.62 \%)$ reflects more the high percentage of bare ground than species abundance.

Table 3. Grass composition, frequency (\%) and Z-index in grazed and ungrazed plots per site

\begin{tabular}{|c|c|c|c|c|c|c|}
\hline \multirow[t]{2}{*}{ Species } & \multicolumn{2}{|c|}{ Austrey } & \multicolumn{2}{|c|}{ Southey } & \multicolumn{2}{|c|}{ Tseoge } \\
\hline & Grazed & Ungrazed & Grazed & Ungrazed & Grazed & Ungrazed \\
\hline Digitaria eriantha & 1.1 & 18.5 & 0 & 0 & 0 & 3.3 \\
\hline $\begin{array}{l}\text { Schmidtia } \\
\text { pappophoroides }\end{array}$ & 4.5 & 11.1 & 1.8 & 4.7 & 0 & 0 \\
\hline $\begin{array}{l}\text { Triraphis } \\
\text { andropogonoides }\end{array}$ & 0 & 0.8 & 1.8 & 6.7 & 0 & 0 \\
\hline $\begin{array}{l}\text { Eragrostis } \\
\text { lehmanniana }\end{array}$ & 8.3 & 14.1 & 5.5 & 6 & 0 & 8.9 \\
\hline Eragrostis trichophora & 21.7 & 5.9 & 0 & 0 & 0 & 0 \\
\hline Aristida stipitata & 18.9 & 20 & 26.1 & 8.7 & 0 & 3.3 \\
\hline Melinis repens & 1.1 & 0 & 3 & 0 & 0 & 0 \\
\hline Eragrostis rigidior & 0.6 & 5.2 & 0 & 0 & 0 & 0 \\
\hline $\begin{array}{l}\text { Pogonarthria } \\
\text { squarrosa }\end{array}$ & 0 & 1.5 & 33.9 & 48.7 & 0 & 0 \\
\hline Aristida congesta & 22.2 & 12.6 & 7.9 & 7.3 & 0 & 7.8 \\
\hline Perotis patens & 1.2 & 1.5 & 0 & 0 & 0 & 0 \\
\hline Tragus berteronianus & 12.2 & 1.5 & 0 & 0 & 0 & 0 \\
\hline Brachiaria marlothii & 1.7 & 0 & 0 & 0 & 20.6 & 13.3 \\
\hline Stripagrostis uniplumis & 0 & 0 & 8.5 & 0.7 & 0 & 0 \\
\hline Bare ground & 6.7 & 7.4 & 6.1 & 14.7 & 79.3 & 63.3 \\
\hline Z-index (\%) & \multicolumn{2}{|c|}{48.34} & \multicolumn{2}{|c|}{57.91} & \multicolumn{2}{|c|}{1.62} \\
\hline
\end{tabular}

\section{Relations between herbaceous composition and soil microbial parameters}

The relationships between vegetation composition and soil microbial biomass and bacterial and fungi PLFA are shown in the canonical correspondence analysis (Fig. 4). The eigenvalues of the two fist axes of the canonical correspondence analysis were 0.483 and 0.195 , respectively. They account for $60.1 \%$ and $24.3 \%$, respectively, thus contributng to $84.4 \%$ of the cumulative percentage variance of the species-environment relation. The first axis of the CCA was strongly correlated with total PLFA $\left(\mathrm{r}^{2}=0.93\right)$, bacterial PLFA $\left(r^{2}=0.91\right)$ and fungal PLFA $\left(r^{2}=0.94\right)$. Soil microbial biomass measured as total PLFA, as well as the bacterial and fungi PLFA showed strong positive correlation with the Austrey site characterized by greater species composition (both grazed and ungrazed plots), as compared to the Southey and Tseoge sites (Fig. 4). 


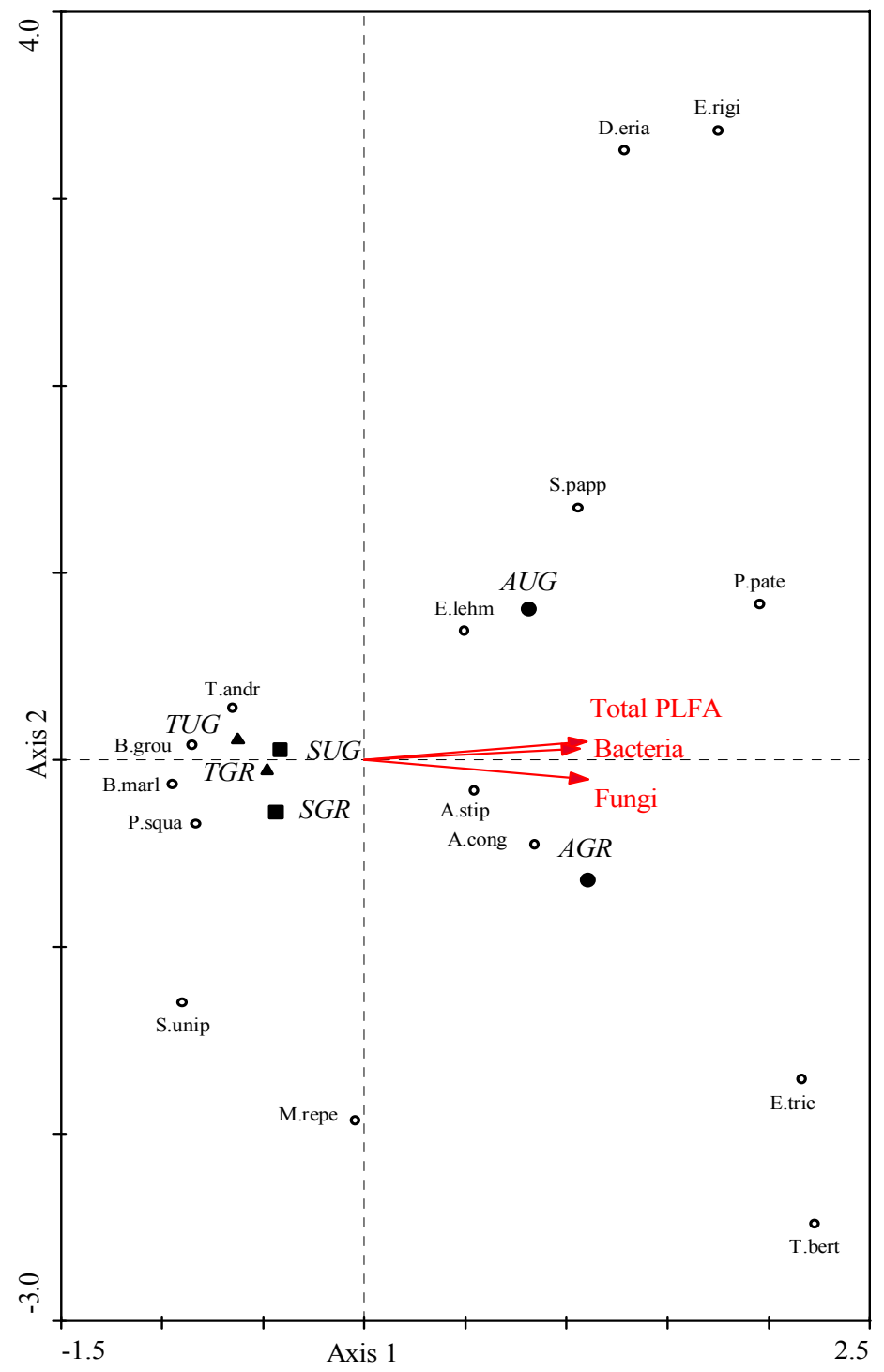

Figure 4. Canonical Correspondence Analysis (CCA) of plant species composition, total PLFA, bacterial and fungal PLFA. Keynote: AGR: Austrey grazed, AUG: Austrey ungrazed, SGR: Southey grazed, SUG: Southey ungrazed, TGR: Tseoge grazed, TUG: Tseoge ungrazed. Species: A.cong: Aristida congesta, A.stip: Aristida stipitata, B.marl: Brachiaria marlothii, D.erian: Digitaria eriantha, E.lehm: Eragrostis lehmanniana, E.rigi: Eragrostis rigidior, E.tric: Eragrostis trichophora, M.repe: Melinis repens, P.pate: Perotis patens, P.squa: Pogonarthria squarrosa, S.papp: Schmidtia pappophoroides, S.unip: Stripagrostis uniplumis, T.andr: Triraphis andropogonoides, T.bert: Tragus berteronianus. B.grou: Bare ground. Eigenvalues: Axis $1=0.483$; Axis $2=0.195$

\section{Discussion}

Results from this study showed that soil organic carbon and soil microbial biomass measured as total PLFA did not statistically differ between the grazed and ungrazed plots at any of the three study sites (Table 2, Fig. 2). Soil microbial biomass was overall 
low in all plots at the three sites, ranging between $489.28 \mathrm{pmol} \mathrm{g}^{-1}$ and $1823.04 \mathrm{pmol} \mathrm{g}^{-1}$. These values are far below those reported in studies of temperate grasslands across the world.

We hypothesized two factors responsible of the findings in this study. Firstly, the low vegetation abundance and cover or state of degradation (Table 3, Fig. 1), which was already extreme in the present investigation, might have induced the low soil microbial biomass at the three sites. Soil microbial biomass is considered part of the available or labile soil organic matter, the small fraction that is readily decomposed and involved in nutrient cycling [35]. Because soil microbial communities rely on materials produced by plants as energy sources for growth and reproduction, low plant cover and biomass would affect the activity of microbial communities. [4], [50] showed that differences in soil microbial biomass are due to gradients in resource availability in particular soil organic matter content. Therefore, declined and degraded plant cover means a lower soil organic matter added to the soil, which will inhibit the activity of soil microorganisms [16]. Our hypothesis was consistent with other results [48], as quoted [16] indicated that soil with a lower plant cover do not have a higher potential microbial activity. A greater depletion of organic carbon in the soil possibly due to reduced quality and quantity of organic matter in soils results in loss in microbial activity [14]. Similar results have also been reported [54], in the sense that the loss of plant species has the greatest impact on microbial communities in ecosystems containing infertile soils poor in organic matter, and that the loss of above and belowground herbaceous materials removed the energy sources required for microbial growth [34].

Soil microbial biomass is a potential source of plant nutrients, and a higher level of soil microbial biomass is an indicator of soil fertility. The soil microbial biomass was higher at Austrey, compared to Southey and Tseoge sites, irrespective of grazing or its exclusion condition. The results in Fig. 4 showed a strong correlation at Austrey site with the soil microbial biomas, as well as bacterial and fungi PLFA. It was evident from the results of Table 3, that the greater species composition and resulting biomass would result in much more organic material, which is vital to stimulate the soil microbial communities. The vegetation condition at Southey site and the higher bare ground at Tseoge $\mathbf{( 7 9 . 3 \% )}$ ) would undoubtedly result in lower soil microbial biomass at these two sites respectively. Our results seem to confirm previous studies, which highlighted the relationships between high plant richness and increases of microbial biomass [40], [11], [7]. Floristically differences between ecosystems would produce litter with chemically distinct substrates that will differentially foster microbial growth [33]. In this study, the grazed and ungrazed plots at all three sites showed similarities in grass composition (Table 3), although Z-index at the Tseoge site was lower (1.62\%) but characterized overall by high percentage of bare ground. The similarity in herbaceous composition may explain the absence of statistically significant difference in soil microbial biomass between the grazed and ungrazed plots. Our results are in concordance with [28], [46] which have reported no statistically significant difference of soil microbial biomass between grazed and ungrazed rangelands protected of grazing for 16 and 35-40 years in temperate grasslands.

Our second hypothesis referred to the effect of livestock grazing and its management between the three sites. Despite the low soil microbial biomass, there was a statistically significant difference between the grazed plots at the three sites $(\mathrm{p}=0.03)$, with the 
Austrey site showing "relatively" higher soil microbial biomass (Fig. 2). A reduction of microbial biomass carbon in soils of areas subjected to poor grazing management has been reported [25]. As grazing influences plant growth and composition, this would affect the flow of plant litter to decomposers [46], and consequently the carbon inputs to the belowground microorganisms. Other studies [24], [4] on the contrary have reported that depending on its intensity, grazing may increase the allocation of organic inputs to the soil by rapidly returning plant available nutrients in the form of dung and faeces. Resulting from this allocation, soils of grazed grasslands tend to have small amounts of dead litter on the soil surface, but contain also large amounts of organic nitrogen and carbon, which combines to produce a soil environment that sustains an abundant and diverse faunal and microbial community [5]. This might not hold true for the present investigation, as there was little vegetation to start-off; and that it was unclear whether the state of vegetation degradation is due to grazing effect and/or its combination with variation of climatic conditions.

\section{Conclusion}

To our knowledge, this study is the first conducted in these communal rangeland sites to assess the patterns of soil microbial biomass. Our results suggest that low vegetation abundance and the poor condition (degradation) was the prime determinant of the low soil microbial biomass found at the three sites. Soil microbial biomass is a potential source of plant nutrients, and higher level of soil microbial biomass is an indicator of soil fertility. In the case of this study, this implies low soil fertility, which will then affect the sustainability of these rangeland sites. Despite the short-time period of this study, our results are in concordance with global literature that plant abundance and cover determines microbial metabolism, although thorough comparisons with previous studies were very difficult, because of different soils condition, initial vegetation state and cover, duration, intensity and management of grazing. It was unclear was whether the state of the vegetation was a result of grazing influence and management or combined effects of grazing and climatic variation. Therefore, further research is required for a thorough understanding of the underlying processes (grazing, changes in vegetation condition, climate variation) that may regulate changes in the soil microbial biomass in order to promote sustainable management of these communal rangelands.

Acknowledgements. The authors thank the Desert Margins Program (DMP/GEF) for funding this study. The financial support of the Tropical Soil Biology and Fertility (TSBFI-CIAT Nairobi, Kenya) is highly appreciated. The authors express their appreciation to the North West Department of Agriculture, Conservation, Environment and Tourism for the assistance in collecting soil samples (J. van Rooyen, E. Mokua, D. Dikobe, F. April, and F. Derk), and to Marisa Coetzee for the vegetation data. The research was supported by the International Foundation for Science, Stockholm, Sweden and the United Nations University (UNU) Tokyo, Japan, through a grant to Mr. Abdoulaye Saley Moussa. Thanks to C. van Zyl for editing the draft manuscript, and the anonymous reviewers for their comments on the manuscript.

\section{REFERENCES}

[1] Abel, N.O.J. (1993): Reducing cattle numbers on southern African communal range: is it worth it? - In: Behnke RH, Scoones I, Kerven C (Eds.), Range Ecology at Desiquilibrium, pp 173-195. London IIED \& Commenwealth Secretariat 
[2] Acocks, J.P.H. (1988): Veld types of South Africa. Memoirs of the Botanical survey of South Africa no 57, $146 \mathrm{pp}$

[3] Bailey, V.L., Peacock, A.D., Smith, J.L., Bolton Jr, H. (2002): Relationships between soil microbial biomass determined by cholroform fumigation-extraction, substrate-induced respiration, and phospholipid fatty acid analysis. - Soil Biology \& Biochemistry 34: 13851389

[4] Bardgett, R.D., Leemans, D.K., Cook, R., Hobbs, P.J. (1997): Seasonality of the soil biota of grazed and ungrazed hill grasslands. - Soil Biology and Biochemistry 29: 1285-1294

[5] Bardgett, R.D., Cook, R. (1998): Functional aspects of soil animal diversity in agricultural grasslands. - Applied Soil Ecology 10: 263-276

[6] Bardgett, R.D., Wardle, D.A., Yeates, G.W. (1998): Linking above-ground and belowground food webs: how plant responses to foliar herbivory influence soil organisms. - Soil Biology \& Biochemistry 30: 1067-1078

[7] Bardgett, R.D., Shine, A. (1999): Linkages between plant litter diversity, soil microbial biomass and ecosystem function in temperate grasslands. - Soil Biology \& Biochemistry 31: 317-321

[8] Bending, G.D., Turner, M.K., Rayns, F., Marx, M-C., Wood, M. (2004): Microbial and biochemical soil quality indicators and their potential for differentiating areas under contrasting agricultural management regimes. - Soil Biology \& Biochemistry 36: 17851792

[9] Bligh, E.G., Dyer, W.J. (1959): A rapid method of total lipid extraction and purification. Canadian Journal of Biochemical Physiology 37: 911-917

[10] Bray, R.H., Kurtz, L.T. (1945): Determination of total, organic and available forms of phosphorus in soils. - Soil Science 59: 39-45

[11] Broughton, L.C., Gross, K.L. (2000): Patterns of diversity in plant and soil microbial communities along a productivity gradient in a Michigan old-field. - Oecologia 125: 420427

[12] Claassens, S., Riedel, K.J., Van Rensburg, L., Morgenthal, T.L. (2005): Soil microbial properties in coal mine tailings under rehabilitation. - Applied Ecology and Environmental Research 4: 75-83

[13] Corwin, D.L., Lescha, S.M., Oster, J.D., Kaffka, S.R. (2005): Monitoring managementinduced spatio-temporal changes in soil quality through soil sampling directed by apparent electrical conductivity. - Geoderma in press doi 10.1016/j.geoderma.2005.03.014

[14]Degens, B.P., Schipper, L.A., Sparling, G.P., Vojvodic-Vukovic, M. (2000): Decreases in organic $\mathrm{C}$ reserves in soil can reduce the catabolic diversity of soil microbial communities. - Soil Biology \& Biochemistry 32: 189-196

[15] Du Toit, P.C.V. (1998): Research note: grazing index method procedures of vegetation surveys. - African Journal of Range and Forage Science 14: 107-110

[16] Garcia, C., Hernandez, T., Roldan, A., Martin, A. (2002): Effect of plant cover decline on chemical and microbiological parameters under Mediterranean climate. - Soil Biology \& Biochemistry 34: 635-642

[17] Giller, K.E., Beare, M.H., Lavelle, O., Izac, A-M.N., and Swift, M.J. (1997): Agricultural intensification, soil biodiversity and ecosystem function. - Applied Soil Ecology 6: 3-16

[18] Grayston, S.J., Wang, S., Campbell, C.D., Edwards, A.C. (1998): Selective influence of plant species on microbial diversity in the rhizosphere. - Soil Biology \& Biochemistry 30: 369-378

[19] Grayston, S.J., Griffith, G.S., Mawdsley, J.L., Campbell, C.D., Bardgett, R.D. (2001): Accounting for variability in soil microbial communities of temperate upland grassland ecosystems. - Soil Biology \& Biochemistry 33: 533-551

[20] Grayston, S.J., Campbell, C.D., Bardgett, R.D., Mawdsley, J.L., Clegg, C.D., Ritz, K., Griffiths, B.S., Rodwell, J.S., Edwards, S.J., Davies, W.J., Elston, D.J., Millard, P. (2004): Assessing shifts in microbial community structure across a range of grasslands of different 
management intensity using CLPP, PLFA and community DNA techniques. - Applied Soil Ecology 25: 63-84

[21] Guckert, J.B., Antworth, C.P., Nichols, P.D., White, D.C. (1985): Phospholipid ester-linked fatty acid profiles as reproducible assays for changes in prokaryotic community structure of estuarine sediments. - FEMS Microbiology Ecology 31: 147-158

[22] Hargreaves, P.R., Brookes, P.C., Ross, G. J. S., Poulton, P. R. (2003): Evaluating soil microbial biomass carbon as an indicator of long-term environmental change. - Soil Biology \& Biochemistry 35: 401-407

[23] Hofman, J., Bezchlebová, J., Dušek, L., Doležal, L., Holoubek, I., Anděl, P., Ansorgová, Maly, S. (2003): Novel approach to monitoring of soil biological quality. - Environmental International 28: 771-778

[24] Holland, J.N., Cheng, W., Crossley, D.A. (1996): Herbivore-induced changes in plant carbon allocation: assessment of belowground C fluxes using carbon. - Oecologia 107: 8794

[25]Holt, J.A. (1997): Grazing pressure and soil carbon, microbial biomass and enzyme activities in semi-arid northern Australia. - Applied Soil Ecology 5: 143-149

[26] Insam, H. (2001): Developments in soil microbiology since the mid 1960s. - Geoderma 100: $389-402$

[27] Kent, M., Coker, P. (1992): Vegetation description and analysis: a practical approach. John Wiley \& Sons $363 \mathrm{pp}$

[28] Kieft, T.L. (1994): Grazing and plant canopy effects on semi-arid soil microbial biomass and respiration. - Biology \& Fertility of Soils 18: 155-182

[29] Mawdsley, J.L., Bardgett, R.D. (1998): Continuous defoliation of perennial ryegrass (Lolium perenne) and white clover (Trifolium repens) and associated changes in the microbial population of an upland grassland soil. - Biology \& Fertility of Soils 24: 52-58

[30] Mangold, S., Kalule-Sabiti, M., Walmsley, J. (2002): State of the Environment Report 2002 North West Province, South Africa. North West Province Department of Agriculture, Conservation and Environment 2002. $46 \mathrm{pp}$

[31] McCulley, R.L., Burke, I.C. (2004): Microbial community composition across the Great Plains: landscape versus regional variability. - Soil Science Society of America Journal 68: 106-115

[32] Morgenthal, T.L., Van Rensburg, L. (2004): Ecosystem development on seven rehabilitated discard dumps. - African Journal of Range \& Forage Science 21: 57-66

[33] Myers, R.T., Zak, D.R., White, D.C., Peacock, A. (2001): Landscape-level patterns of microbial community composition and substrate use in upland forest ecosystems. - Soil Science Society of America Journal 65: 359-367

[34] Northup, B.K., Brown, J.R., Holt, J.A. (1999): Grazing impacts on the spatial distribution of soil microbial biomass around tussock grasses in a tropical grassland. - Applied Soil Ecology 13: 259-270

[35] Paul, E.A. (1984): Dynamics of organic matter in soils. - Plant and Soil 76: 275-285

[36] Pierce, F.J., Larson, W.E. (1993): Developing criteria to evaluate sustainable land management. - In: Kimble, J.M. (Ed.) Proceedings of the VIII International Soil Management Workshop Utilization of soil survey information for sustainable land use. Sacramento pp. 7-14

[37] Shackleton, C.M. (1993): Are the communal grazing lands in need of saving? Development Southern Africa 10: 65-78

[38] Smet, M., Ward, D. (2006): Soil quality gradients around water-points under different management systems in a semi-arid savanna, South Africa. - Journal of Arid Environments 64: $251-269$

[39] Soil Classification Working Group (1991): Soil Classification: a taxonomic system for South Africa. Memoirs on the Agricultural Natural Resources of South Africa No. 15 $257 \mathrm{pp}$. 
[40] Spehn, E.M., Joshi, J., Schmid, B., Alphei, J., Körner, C. (2000): Plant diversity effects on soil heterotrophic activity in experimental grassland ecosystems. - Plant and Soil 224: 217230

[41] Sparling, G.P. (1997). Soil microbial biomass, activity and nutrient cycling as indicators of soil health. - In: Pankhurst CE, Doube BM, Gupta VVSR (Eds) Biological indicators of soil health. CAB International, Wallingford, Oxon, UK, pp. 97-119

[42] Stohlgren, T.J., Schell, L.D., Heuvel, B.V. (1999): How grazing and soil quality affect native and exotic plant diversity in rocky mountain grasslands. - Ecological Applications 9: 45-64

[43] Tainton, N.M. (1999): Veld management in South Africa. University of Natal Press. Pietermaritzburg. $472 \mathrm{pp}$

[44] Tate, R.L. (2000): Soil microbiology. $2^{\text {nd }}$ Edition. John Wiley \& Sons, Inc. New York, 508 $\mathrm{pp}$

[45] ter Braak, C.F.J., Šmilauer, P. (2002); Reference manual and CanoDraw for Windows user's guide: Software for Canonical Community Ordination (version 4.5). Microcomputer Power (Ithaca, NY, USA), $500 \mathrm{pp}$

[46] Tracy, B.F., Frank, D.A. (1998): Herbivore influence on soil microbial biomass and nitrogen mineralization in a northern grassland ecosystem: Yellowstone National Park. Oecologia 114: 556-562

[47] Van der Putten, W.H., Vet, L.E.M., Harver, J.A., and Wackers, F.L. (2001): Linking above and belowground multitrophic interactions of plants, herbivores, pathogens and their antagonists. - Trends Ecol. Evol. 16: 547-554

[48] Van Veen, J.A., Ladd, J.N., Amato, M. (1985): Turnover of carbon and nitrogen in a sandy loam and a clay soil incubated with ${ }^{14} \mathrm{C}(\mathrm{U})$ glucose and ${ }^{15} \mathrm{~N} \mathrm{NH}_{2} \mathrm{SO}_{4}$ under different moisture regimes. - Soil Biology \& Biochemistry 17: 747-756

[49] Walkley, A. (1935): An examination of methods for determining organic carbon and nitrogen in soils. - Journal of Agricultural Sciences 25: 598-609

[50] Wardle, D.A. (1992): A comparative assessment of factors which influence microbial biomass carbon and nitrogen levels in soils. - Biological Reviews 67: 321-358

[51] Wardle, D.A., Giller, K.E. (1996): The quest for a contemporary ecological dimension to soil biology. - Soil Biology \& Biochemistry 28: 1549-1554

[52] White D.C., Ringelberg, D.B. (1998): Signature lipid biomarker analysis. - In: Burgale, R.S., Atlas, R., Stahl, D., Geesey, G., and Sayler, G., (Eds.), Techniques in microbial ecology. Oxford University Press, NY pp. 255-272

[53] Yeates, G.W., Bardgett, R.D., Cook, R., Hobbs, P.J., Bowling, P.J., Potter, J.F. (1997): Faunal and microbial diversity in three Welsh grassland soils under conventional and organic management regimes. - Journal of Applied Ecology 34: 453-471

[54]Zak, D.R., Holmes, W.E., White, D.C., Peacock, A.D., Tilman, D. (2003): Plant diversity, soil microbial communities, and ecosystem function: are there any links? - Ecology 84: 2042-2050

[55]Zelles, L. (1999): Fatty acid patterns of phospholipids and lipopolysaccharides in the characterization of microbial communities in soil: a review. - Biology \& Fertility of Soils 29: 111-129. 